\title{
EFFECTS OF AEROBIC EXERCISE TRAINING ON OXIDATIVE STRESS IN THE SKELETAL MUSCLES OF OBESE RATS
}

\section{EFEITOS DO TREINAMENTO AERÓBICO SOBRE O ESTRESSE OXIDATIVO EM MÚSCULOS ESQUELÉTICOS DERATOS OBESOS}

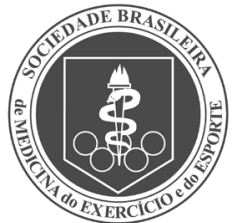

Original Article ARTIGO ORIGINAL Artículo Original

\section{EFECTOS DEL ENTRENAMIENTO AERÓBICO SOBRE EL ESTRÉS OXIDATIVO EN MÚSCULOS ESQUELÉTICOS DERATONES OBESOS}

Ariene Sampaio Souza Farias Ulbricht' (Biologist)

Daniela Delwing-de Lima ${ }^{1,2}$ (Pharmacist and Biochemist) Carla Werlang-Coelho $0^{3,4}$ (Physical Education Professional) Débora Delwing-Dal Magro 5 (Pharmacist and Biochemist) Bruna Donat ${ }^{3}$

(Physical Education Professional) Mariana Ramos Vieira' (Physician) Marina Zordan Poletto' (Physician) Eduardo Manoel Pereira ${ }^{6}$ (Pharmacist and Biochemist)

1. Universidade da Região de Joinville, Department of Medicine, Joinville, SC, Brazil.

2. Universidade da Região de Joinville, Health and Environmental Graduate Studies Program, Joinville, SC, Brazil.

3. Universidade da Região de Joinville, Department of Physical Education, Joinville, SC, Brazil. 4. Universidade do Estado de Santa Catarina, Department of Chemistry, Joinville, SC, Brazil.

5. Universidade Regional de Blumenau, Department of Natural Sciences, Centro de Ciências Exatas e Naturais, Blumenau, SC, Brazil. 6. Universidade da Região de Joinville, Department of Pharmacy, Joinville, SC, Brazil.

\section{Correspondence:}

Daniela Delwing-de Lima.

Rua Paulo Malschitzki, 10, Zona

Industrial Norte, Joinville, SC, Brazil. 89201-972.

danidelwing@hotmail.com; daniela.delwing@univille.br

\begin{abstract}
Introduction: Obesity is a complex and multifactorial metabolic disorder characterized by the accumulation of body fat; physical exercise increases energy expenditure and promotes a reparative effect through modulation of endogenous antioxidant defenses. Objective:To evaluate the effects of the high-fat diet (HFD) on oxidative stress parameters in skeletal muscles of rats using aerobic exercise training protocols (AETP), moderate-intensity continuous training (MICT) and high-intensity interval training (HIIT). Methods: The study was quantitative and experimental. Animals received 8 weeks of HFD or normal diet (ND), followed by 9 weeks of HFD or ND and the two AETPs. Results: HFD did not alter the formation of thiobarbituric acid reactive substances (TBA-RS), total sulfhydryl and protein carbonyl content in the soleus and plantaris muscles; in contrast, the protocols caused a decrease in TBA-RS levels in the plantaris muscle and increased the sulfhydryl content in the soleus muscle, while MICT increased the sulfhydryl content in the plantaris muscle and reduced protein carbonyl content in both muscles. HFD reduced SOD activity in the plantaris muscle while the MICT protocol enhanced SOD in the soleus muscle and both protocols reversed the decrease in SOD in the plantaris muscle. HFD increased CAT activity in the soleus muscle, the HIIT protocol prevented this alteration and both protocols increased CAT in the plantaris muscle. HFD reduced GSH-Pxactivity in both muscles, and the MICT protocol prevented this reduction in the soleus muscle, while the HIIT protocol partially prevented this decrease. The MICT protocol did not prevent the reduction of GSH-Px and the HIIT protocol partially prevented this decrease in the plantaris muscle. Conclusions: HFD elicited oxidative stress in the skeletal muscle of rats, and both protocols were able to prevent most of the alterations in oxidative stress parameters caused by the HFD. Level of evidence IV; Investigation of treatment outcomes.
\end{abstract}

Keywords: Protocols; Oxidative stress; Skeletal muscle.

\section{RESUMO}

Introdução: Obesidade éuma desordem metabólica complexa e multifatorial, caracterizada pelo acúmulo de gordura corporal. O exercício físico tem a capacidade de aumentar o gasto energético e promover efeito reparador por meio da modulação das defesas antioxidantes endógenas. Objetivo: Avaliar os efeitos da dieta hiperlipídica (DHL) sobre parâmetros de estresse oxidativo em músculos esqueléticos de ratos, por protocolos de treinamento físico aeróbico (TFA), treinamento contínuo de intensidade moderada (TCIM) e treinamento intervalo de alta intensidade (HIIT). Métodos: O estudo foi quantitativo e experimental. Animais receberam 8 semanas de DHL ou dieta normal (DN), seguidas por 9 semanas de DHL ou DN eos dois TFA. Resultados: A DHL não alterou a formação de substâncias reativas ao ácido tiobarbitúrico (TBA-RS), conteúdo total de sulfidrilas e de proteínas carboniladas nos músculos sóleo e plantar. Em contraste, os protocolos diminuíram TBA-RS no músculo plantar e aumentaram o conteúdo de sulfidrilas no músculo sóleo. TCIM aumentou o conteúdo de sulfidrilas no músculo plantar e reduziu o conteúdo de proteínas carboniladas em ambos os músculos. A DHL reduziu a atividade da SOD no músculo plantar; O TCIM aumentou a SOD no músculo sóleo e ambos os protocolos reverteram a diminuição da SOD no músculo plantar. A DHL aumentou a CAT no músculo sóleo, o HIIT preveniu essa alteração e ambos os protocolos aumentaram a CAT no músculo plantar. A DHL diminuiu a atividade da GSH-Pxem ambos os músculos, eo TCIM preveniu esta diminuição no músculo sóleo, enquanto que o HIIT preveniu parcialmente esta diminuição. O TCIM não preveniu a redução da GSH-Px, e o HIIT preveniu parcialmente esta diminuição no músculo plantar. Conclusão: A DHL causouestresse oxidativo nos músculos esqueléticos de ratos, e ambos os protocolos foram capazes de prevenir a maioria das alterações nos parâmetros de estresse oxidativo causadas pela DHL. Nível de evidência IV; Investigação dos resultados do tratamento.

Descritores: Protocolos; Estresse oxidativo; Músculo esquelético.

\section{RESUMEN}

Introducción: La obesidad es un desorden metabólico complejo y multifactorial caracterizado por la acumulación de grasa corporal. El ejercicio fisico tiene la capacidad de aumentar el gasto energético y promover efecto reparador por medio de la modulación de las defensas antioxidantes endógenas. Objetivos: Evaluarlos efectos de la dieta hiperlipídica (DHL) sobre parámetros de estrés oxidativo en los músculos esqueléticos de las ratas, por protocolos de entrenamiento físico aeróbico (TFA), entrenamiento continuo de intensidad moderada (TCIM) yentrenamiento de intervalo de alta intensidad (HIIT). Métodos: Elestudio fue cuantitativo y experimental. Los animales recibieron ocho semanas de DHL o dieta normal (DN), seguidas por nueve semanas de DHL o DN 
y los dos TFA. Resultados: La DHL no alteró la formación de sustancias reactivas al ácido tiobarbitúrico (TBA-RS), contenido total de sulfhidrilos y de proteínas carboniladas en los músculos sóleo y plantar. En contraste, los protocolos disminuyeron TBA-RS en el músculo plantary aumentaron el contenido de sulfhidrilos en el músculo sóleo. TCIM aumentó el contenido de sulfhidrilos en el músculo plantar y redujo el contenido de proteínas carboniladas en ambos músculos. La DHL redujo la actividad de la SOD en el músculo plantar, el TCIM aumentó la SOD en el músculo sóleo y ambos protocolos revirtieron la disminución de la SOD en el músculo plantar. La DHL aumentó la CAT en el músculo sóleo, el HIIT previno esa alteración y ambos protocolos aumentaron la CAT en el músculo plantar. La DHL disminuyó la actividad de GSH-Px en ambos músculos, yel TCIM previno esta disminución en el músculo sóleo, mientras que el HIIT previno parcialmente esta disminución. EI TCIM no previno la reducción de la GSH-Pxy el HIIT previno parcialmente esta disminución en el músculo plantar. Conclusión: La DHL causóestrés oxidativo en los músculos esqueléticos de ratones y ambos protocolos fueron capaces de prevenir la mayoría de las alteraciones en los parámetros deestrés oxidativo causados por DHL. Nivel de evidencia IV; Investigación de los resultados del tratamiento.

Descriptores: Protocolos; Estrés oxidativo; Músculo esquelético.

\section{INTRODUCTION}

Obesity is a chronic disease characterized by the excessive accumulation of triglycerides in adipose tissue, due to the energy imbalance between a high intake of foods with high fat and sugar content and a reduced energy consumption. This condition, which can be measured by the Index Body mass (BMI), has a complex etiology, as a result of interactions between genetic, metabolic and environmental factors. ${ }^{1}$

Simultaneously, obesity is also a risk factor for cardiovascular diseases, such as hypertension and atherosclerosis, and metabolic endocrine-diseases, such as diabetes mellitus type 2 . This interaction occurs as a consequence of abnormal bio-metabolic processes, including endothelial dysfunction. ${ }^{2}$ Obesity is also associated with the induction of cellular events that can lead to the mitochondrial production of reactive oxygen species (ROS), via the respiratory chain. ${ }^{3,4}$ According to Pimenta et al., ${ }^{5}$ diets that are high in fat exacerbate the deleterious effects of free radicals in the animal model.

Multiple therapies have been suggested as approaches to reduce the harmful results of obesity and its comorbidities, among these are the conducts that aim to minimize its deleterious effects at the cellular and systemic levels. ${ }^{6-9}$ Studies have proven that regular and systematic physical activity is beneficial in the prevention and rehabilitation of damage to health, since it can regulate metabolic control, activating and amplifying the functioning of all organs. Among the models of exercises, we highlight interval and continuous exercise. ${ }^{10,11}$ Interval training is performed intermittently, and is characterized by alternating periods of exercise, combined with rest intervals, while continuous training is characterized by the execution of low and medium intensity exercise, for a period of time, with recovery only after termination of exercise. ${ }^{5,12-13}$ Considering the high global rates of obesity, in association with physical inactivity and the dietary changes that result from popular lifestyles ${ }^{14}$, this study aimed to evaluate the effects of two aerobic exercise training protocols (AETP), moderate-intensity continuous training (MICT) and high-intensity interval training (HIIT), on the alterations caused by a high-fat diet (HFD) on oxidative stress parameters in the soleus and plantaris muscles of rats.

\section{MATERIALS AND METHODS}

Adult male Wistar rats (70 days old) were obtained from the UNIVALI (Universidade do Vale de Itajaí, Brazil) and were randomly assigned into groups fed on a HFD (protein, 20\%; carbohydrate, 20\%; lipid, 60\% - Prag Soluções Biosciências, Jaú-SP) or normal diet (ND) (protein, 20 kcal\%; carbohydrate, 70 kcal\%; lipid, 10 kcal\%; - Nuvital Nutrientes, Curitiba-PR) for 8 -weeks. The rats were maintained on a light-dark inverted cycle (12:12-h light-dark cycle), controlled temperature $\left(22 \pm 1^{\circ} \mathrm{C}\right)$ and free access to the respective diets and tap water. Upon completion of the 8-weeks of diet, animals from the HFD were randomly assigned to the untrained group (HFD-UNT; $n=6$ ) or one of the groups that were trained with the different AETPs (HFD-MICT, $n=6$ and HFD-HIIT, n=6). Animals from the ND were assigned to an untrained group (ND-UNT; $n=6$ ). After, these 4 experimental groups were submitted to 9 more weeks of diet and training. Rats were euthanized three days after the last day of training. This study was performed in accordance with the "Principles of Laboratory Animal Care" (NIH publication 85-23, revised 1985), and was approved by the UNIVILLE (Universidade da Região de Joinville, Joinville, Brazil) Ethics Committee (Protocol No. 002/213 - COEA). All chemicals used in the analysis of oxidative stress parameters were purchased from Sigma Chemical Co., St Louis, MO, USA.

Before the AETP, rats were conditioned to Graded treadmill exercise test, the rats were placed on the treadmill and allowed to acclimatize for at least 10 minutes, later the rats run until exhaustion at $20^{\circ}$ inclination; the speed was started at $6 \mathrm{~m} / \mathrm{min}$ and was increased by $3 \mathrm{~m} / \mathrm{min}$ every 3 min until rats were unable to run. ${ }^{15}$ Both AETPs consisted of an 8 -weeks program of running, 5 days a week.

(1) MICT: was performed at a treadmill speed corresponding to $60 \%$ of the maximum running speed, which was kept unchanged throughout the entire session. (2) HIIT: the rats ran for 3 min at $60 \%$ of the maximum running speed, followed by 4 -min intervals at $85 \%$ of the maximum running speed, which was repeated seven times, session lasted for 49 min., the MICT and HIIT protocols were of matched volume. ${ }^{16}$ HFD-UNT and ND-UNT animals were placed on the treadmill twice a week for $10 \mathrm{~min}$ each day at $40 \%$ of the maximum running speed to maintain running skills.

After decapitation, the skeletal muscle soleus and plantaris were removed and kept in ice-cold buffered sodium phosphate. The skeletal muscles were homogenized in ten volumes (1:10w/v) of $20.0 \mathrm{mM}$ sodium phosphate buffer, pH 7.4, containing $140.0 \mathrm{mM} \mathrm{KCl}$. Homogenates were prepared by passing 5 pulses and were centrifuged at $750 \mathrm{x}$ for 10 min at $4^{\circ} \mathrm{C} .{ }^{17}$ The pellet was discarded and the supernatant was saved in aliquots and stored at $-80^{\circ} \mathrm{C}$.

TBA-RS were determined according to the method described by Ohkawa et al. ${ }^{18}$ Tissues were mixed with 20\% trichloroacetic acid and $0.8 \%$ thiobarbituric acid and heated in a boiling water bath for $60 \mathrm{~min}$. TBA-RS were determined by the absorbance at $535 \mathrm{~nm}$. TBA-RS content was calculated as nanomoles of MDA formed per milligram of protein.

The sulfhydryl content was determined by the method of Aksenov and Markesbery. ${ }^{19} 50 \mu \mathrm{L}$ of homogenate were added to $1 \mathrm{~mL}$ of phosphate-buffered saline (PBS), pH 7.4, containing $1 \mathrm{mM}$ ethylenediaminetetraacetic acid. The reaction was started by the addition of $30 \mu \mathrm{L}$ of $10 \mathrm{mM}$ 5,5'-dithiobis-(2-nitrobenzoic acid) (DTNB) and incubated for 30 min at room temperature in a dark room. Total sulfhydryl content was determined by the absorbance at $412 \mathrm{~nm}$. Results were reported as nmol 3-thio-2-nitrobenzoic acid (TNB)/mg protein. 
Carbonyl content was assayed by a method of Reznick and Packer. ${ }^{20}$ $200 \mu \mathrm{L}$ of homogenate were added containing $400 \mu \mathrm{L}$ of $10 \mathrm{mM}$ dinitrophenylhydrazine (prepared in $2 \mathrm{M} \mathrm{HCl}$ ). Samples were kept in the dark for $1 \mathrm{~h}$ and vortexed every $15 \mathrm{~min}$., $500 \mu \mathrm{L}$ of $20 \%$ trichloroacetic acid were added, was vortexed and centrifuged at 14,000 $\mathrm{g}$ for $3 \mathrm{~min}$. The pellet was washed with $1 \mathrm{~mL}$ ethanol/ethyl acetate, vortexed and centrifuged at 14,000 $x \mathrm{~g}$ for $3 \mathrm{~min}$. The pellet re-suspended in $600 \mu \mathrm{L}$ of $6 \mathrm{M}$ guanidine (prepared in a $20 \mathrm{mM}$ potassium phosphate solution, $\mathrm{pH} 2.3$ ), before vortexing and incubating at $60^{\circ} \mathrm{C}$ for $15 \mathrm{~min}$. Samples were then centrifuged at 14,000 $\times \mathrm{g}$ for 3 min and the supernatant was used to measure absorbance at $370 \mathrm{~nm}$. Results are reported as carbonyl content (nmol/mg protein).

CAT activity was assayed by the method of Aebi. ${ }^{21}$ The method is based on the disappearance of $\mathrm{H}_{2} \mathrm{O}_{2}$ at $240 \mathrm{~nm}$ in a reaction medium containing $20 \mathrm{mM} \mathrm{H}_{2} \mathrm{O}_{2}, 0.1 \%$ Triton X-100, $10 \mathrm{mM}$ potassium phosphate buffer, $\mathrm{pH} 7.0$, and $0.1-0.3 \mathrm{mg}$ protein $/ \mathrm{mL}$. The specific activity is calculated as CAT units/mg protein.

GSH-Px activity was measured by the method of Wendel. ${ }^{22}$ The medium contained $2 \mathrm{mM} \mathrm{GSH}, 0.15 \mathrm{U} / \mathrm{mL}$ GSH reductase, $0.4 \mathrm{mM}$ azide, $0.5 \mathrm{mM}$ tertbutyl- hydroperoxide and $0.1 \mathrm{mM}$ NADPH. The activity is presented as GSH-Px units/mg protein.

SOD activity is based on the capacity of pyrogallol to autoxidize. ${ }^{23}$ The medium contained $15 \mu \mathrm{L}$ of sample, $215 \mu \mathrm{L}$ of a mixture containing $50 \mu \mathrm{M}$ Tris buffer, pH 8.2, 1 MM EDTA, $30 \mu \mathrm{M}$ CAT and $20 \mu \mathrm{L}$ of pyrogallol. The absorbance recorded every 30 seconds for 3 minutes at $420 \mathrm{~nm}$ spectrophotometer. The specific activity is reported as SOD units/mg protein.

Protein was measured by the method of Lowry et al., ${ }^{24}$ using serum bovine albumin.

\section{Statistical analysis}

The data are presented as means and standard error of the means (mean \pm SEM). One-way ANOVA with post hoc testing by Duncan was used. Statistical significance was considered achieved when the $p$-value was $<0.05$. We used the statistical program SPSS for Windows version 12.

\section{RESULTS}

We initially verified the effects of two protocols of AET, HIIT and MICT, on TBA-RS and total sulfhydryl content and total carbonyl content in the soleus and plantaris muscles of rats submitted to HFD.

Figure 1 A shows that HFD did not alter TBA-RS in the soleus and plantaris muscles. The HIIT and MICT did not alter this parameter in the soleus muscle, but caused a decrease in TBA-RS levels in the plantaris muscle, when compared to the HFD-UNT group ( $p<0.05)$. HFD did not alter the total sulfhydryl content (Figure 1B) in the muscles. Both protocols increased total sulfhydryl content in the soleus muscle, while the MICT protocol also increased total sulfhydryl content in the plantaris muscle of rats. HFD did not alter protein carbonyl content (Figure 1C) in the soleus and plantaris muscles, when compared to the control groups (ND-UNT). The HIIT protocol did not alter protein carbonyl content in the plantaris and soleus muscles; the MICT protocol significantly reduced the levels of protein carbonyl content in both types of skeletal muscles, when compared to the HFD-UNT group $(p<0.05)$.

The effects of the two AET protocols were also investigated by evaluating the activities of the antioxidant enzymes. As can be seen in Figure 2A, HFD did not alter SOD activity in the soleus muscle of the HFD-UNT group, but reduced this enzyme's activity in the plantaris muscle, when compared to the ND-UNT group ( $p<0.05)$. The MICT protocol enhanced SOD activity in the soleus muscle, when compared to the HFD-UNT group $(p<0.5)$. Both protocols reversed the decrease in SOD activity caused by HFD in the plantaris muscle of rats $(p<0.05)$. Figure $2 B$ shows that HFD increased CAT activity in the soleus muscle of the HFD-UNT group, when compared to the ND-UNT group, $(p<0.05)$ and did not alter this enzyme activity in the plantaris muscle. The HIIT protocol prevented this alteration
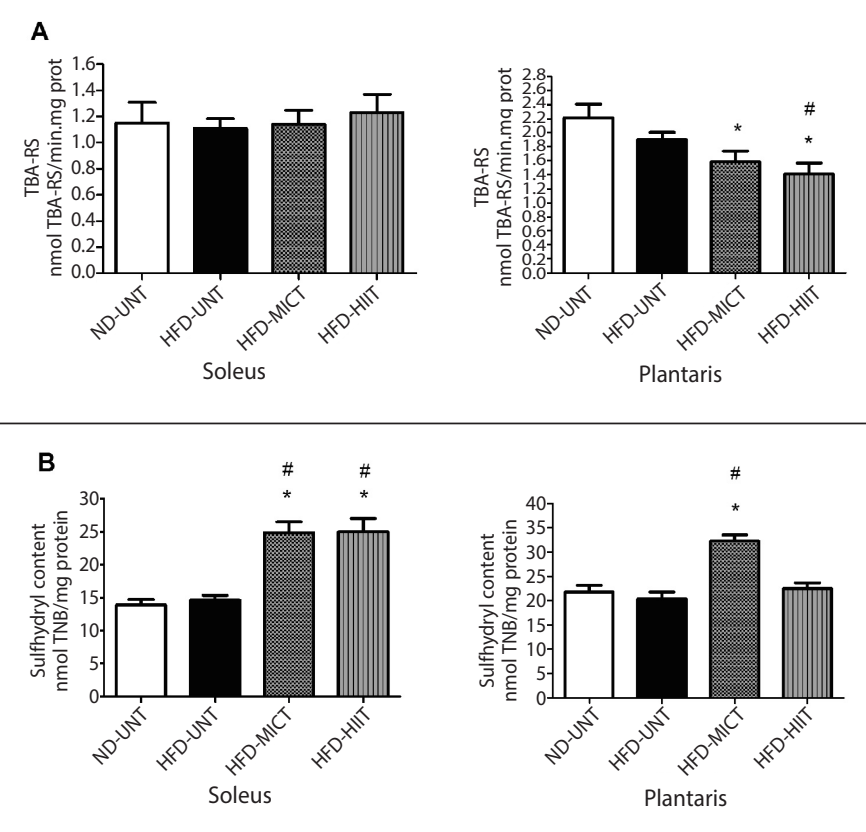

C
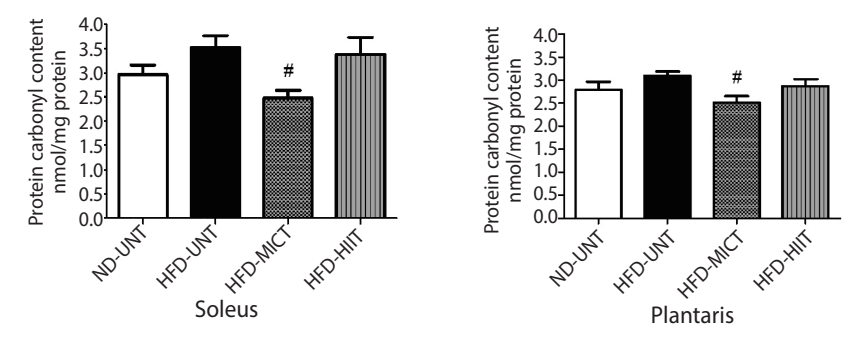

*, $\mathrm{p}<0.05$ vs. ND-UNT; \#, $\mathrm{p}<0.05$ vs. HFD-UNT.

Figure 1. Oxidative stress parameters, $(A)$ thiobarbituric acid reactive substances (TBA-RS); (B) total sulfhydryl content; and (C) protein carbonyl content in the soleus and plantaris muscles of rats from four groups: ND-UNT (normal diet and untrained; $n=6$ ), HFD-UNT (high-fat diet and untrained; n=6), HFD-MICT (high-fat diet and moderate-intensity continuous training; $n=6$ ) and HFD-HIIT (high-fat diet and high-intensity interval training; $n=6)$. Data are presented as means \pm SEM and were compared between groups by one-way analysis of variance (ANOVA) with a post-hoc Duncan test.

in the soleus muscle, when compared the result to the HFD-UNT group $(p<0.05)$ and both protocols increased the activity of CAT in the plantaris muscle $(p<0.05)$. Figure $2 \mathrm{C}$ shows that HFD reduced GSH-Px activity in both muscles in the HFD-UNT group, when compared to the ND-UNT group ( $p<0.05)$. The MICT protocol prevented this reduction in the soleus muscle, while the HIIT protocol partially prevented it when compared to the HFD-UNT group. The MICT protocol did not prevent the reduction in GSH-Px activity in the plantaris muscle, but the HIIT protocol was able to partially prevent the reduction in GSH-Px activity that was observed in the HFD-UNT group $(p<0.05)$.

\section{DISCUSSION}

Obesity is strongly related to oxidative stress; as physical exercise increases the body's energy expenditure and stimulates endogenous antioxidant defenses, it is considered to be an important resource to provide a balance for pro oxidant damage and impaired antioxidant repair mechanisms. ${ }^{25,26}$ The aim of the present study was to investigate the effect of two different protocols of AET, HIIT and MICT, on the oxidative stress profiles of the soleus and plantaris muscles of rats submitted to a HFD.

Our recent study showed that HFD causes oxidative stress in the blood and liver of rats and that both AET protocols (MICT and HIIT) prevented most of the alterations elicited by HFD on oxidative stress parameters. ${ }^{27}$ According to our results, although HFD did not alter TBA-RS levels, nor total 
A
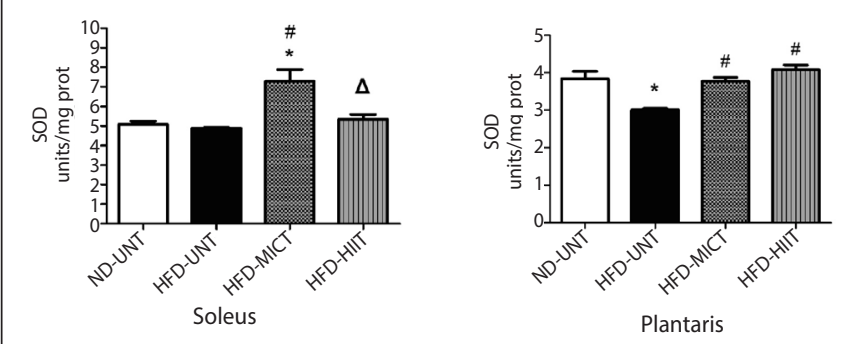

B
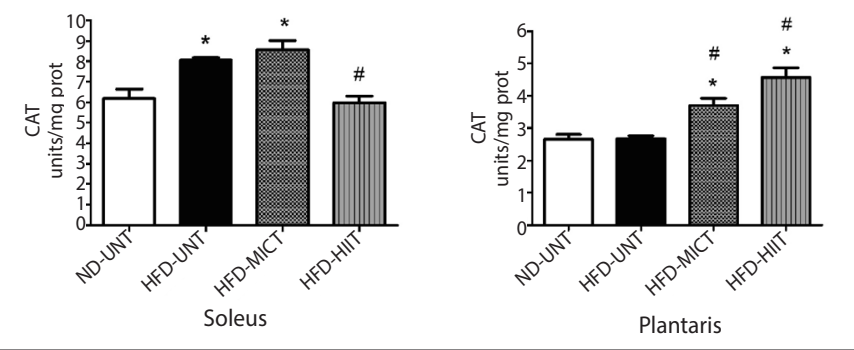

C
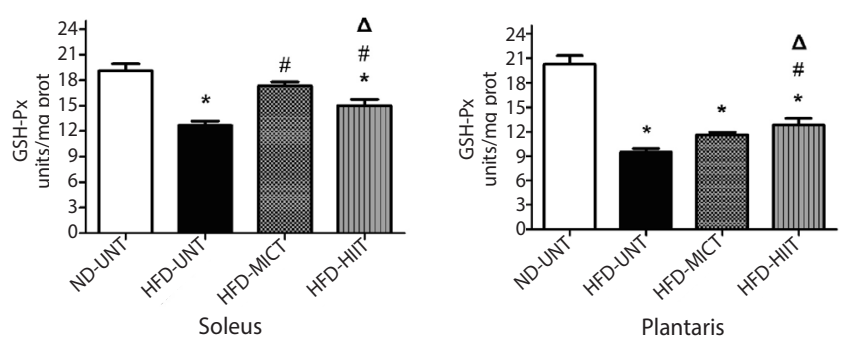

${ }^{*}, \mathrm{p}<0.05$ vs. ND-UNT; $\#, \mathrm{p}<0.05$ vs. HFD-UNT;,$+ \mathrm{p}<0.05$ vs. ND-UNT and HFD-UNT.

Figure 2. Activities of the antioxidant enzymes, (A) superoxide dismutase (SOD), (B) catalase (CAT) and (C) glutathione peroxidase (GSH-Px) in the soleus and plantaris muscles of rats from four experimental groups: ND-UNT (normal diet and untrained; $n=6$ ), HFD-UNT (high-fat diet and untrained; n=6), HFD-MICT (high-fat diet and moderate-intensity continuous training; $\mathrm{n=6}$ ) and HFD-HIIT (high-fat diet and high-intensity interval training; $n=6$ ). Data are presented as means \pm SEM and were compared between groups by one-way analysis of variance (ANOVA) with a post-hoc Duncan test.

sulfhydryl content and the levels of protein carbonyl content, both types of exercise reduced TBA-RS levels in the plantaris muscle, suggesting that aerobic physical activity, in the long term, can be effective in reducing lipid peroxidation in this muscle. In addition, our results suggest that aerobic exercise also prevents protein damage, since both protocols increased total sulfhydryl content in the soleus muscle, and the MICT protocol increased the total sulfhydryl content in the plantaris muscle of rats. In association with the prevention of protein damage, the MICT protocol also showed a tendency towards reducing the levels of protein carbonyl content in both types of skeletal muscles. These results corroborates a well-known positive effect of physical exercise on oxidative stress biomarkers. ${ }^{28}$

With regard to the antioxidant enzymes, results showed that HFD did not alter SOD activity in the soleus muscle, but reduced this enzyme's activity in the plantaris muscle. The MICT protocol enhanced SOD activity in the soleus muscle and both protocols reversed the decrease in SOD activity caused by HFD in the plantaris muscle of rats. With regard to the activity of CAT, HFD increased this enzyme's activity in the soleus muscle, but did not alter this enzyme's activity in the plantaris muscle. The HIIT protocol prevented this alteration in the soleus muscle and both protocols increased CAT activity in the plantaris muscle. HFD reduced the activity of the GSH-Px enzyme in both muscles and the MICT protocol was able to prevent this alteration completely in the soleus muscle, while the HIIT protocol partially prevented it. In contrast, the MICT protocol did not prevent the reduction in GSH-Px activity in the plantaris muscle, however, the HIIT protocol was able to partially prevented this reduction. This imbalance caused by HFD may represent a risk to the antioxidant system over the longer term, due to the important role that antioxidant enzymes play in the reduction of superoxide and hydrogen peroxide and in DNA protection. ${ }^{29}$

Pimenta et al. ${ }^{5}$ reported that HFD exacerbates the deleterious effects of free radicals. In contrast, moderately intense exercise routines have been shown to increase immune defenses. Motta et al. ${ }^{30}$ found an increased expression of antioxidant enzymes in a trained animal model, where a short-term HIIT protocol was seen to attenuate oxidative stress and regulate antioxidant activity, after nine training sessions. Oh et al. ${ }^{31}$ and Delwing-de lima et al. ${ }^{27}$ showed physical training to be effective in reducing serum levels of inflammatory and oxidative stress markers, such as TBA-RS. Additionally, Aguiar Júnior and Pinho ${ }^{32}$ showed that aerobic exercise training increases antioxidant defenses and functional adaptations against oxidative stress by the organism.

The expressions of antioxidant enzymes by skeletal muscle are suggested to be modulated by patterns of activity, including intensity, duration and type, resulting in a variability of effects on the antioxidant enzymes. ${ }^{33}$ Our results show that both types of AET protocols positively modulated the SOD and CAT enzymes in the skeletal muscles studied, but were less effective at modulating GSH-Px enzyme activity. Corroborating previous studies, both types of aerobic exercise diminished oxidative stress parameters in the soleus and plantaris muscles of rats submitted to HFD, by altering the activity of antioxidant enzymes and tending to reduce lipid peroxidation and protein damage. These positive results agree with recent studies showing adaptations of the antioxidant system following higher intensity exercise training. ${ }^{34,35}$ Our results also suggest that the amount of daily training, the time of training and the type of aerobic exercise chosen are also essential for positively modulating this process.

\section{CONCLUSION}

In conclusion, our findings show that obesity alters the activity of antioxidant enzymes in the soleus and plantaris muscles, and that both types of AETP (MICT and HIIT) were effective at modulating the enzymatic system, providing greater protection to muscles against the oxidative damage caused by obesity.

\section{ACKNOWLEDGEMENTS}

This work was supported by grants from Universidade da Região de Joinville.

All authors declare no potential conflict of interest related to this article

AUTHORS' CONTRIBUTIONS: Each author contributed individually and significantly to the development of this article. ASSFU (0000-0001-5819-3560)*: experimentation, statistical analysis, interpretation of the data, writing of the article, review of the article, final approval of the manuscript version to be published; DD-deL (0000-0001-5335-5102)*: experimentation, statistical analysis, interpretation of the data, writing of the article, review of the article, final approval of the manuscript version to be published; CW-C (0000-0002-4606-2966)* experimentation, statistical analysis, interpretation of the data, writing of the article, review of the article, final approval of the manuscript version to be published; DD-DM (0000-00034459-1562)*: experimentation, statistical analysis, interpretation of the data, writing of the article, review of the article, final approval of the manuscript version to be published; BD (0000-0002-5086-5198)*: experimentation, review of the article, final approval of the manuscript version to be published; MRV (0000-0003-0944-8402)*: experimentation, review of the article, final approval of the manuscript version to be published; MZP (0000-0002-8976-8918)*: experimentation, review of the article, final approval of the manuscript version to be published; EMP (0000-0002-5734-626X)*: experimentation, statistical analysis; interpretation of the data, writing of the article, review of the article; final approval of the manuscript version to be published. ${ }^{*} \mathrm{ORCID}$ (Open Researcher and Contributor ID). 


\section{REFERENCES}

1. Curi R, Pompeia C, Miyasaka CK, Procópio J. Entendendo a Gordura. Os Ácidos Graxos. São Paulo: Manole; 2002.

2. Huang CJ, McAllister MJ, Slusher AL, Webb HE, Mock JT, Acevedo EO. Obesity-related oxidative stress: the impact of physical activity and diet manipulation. Sports Med. 2015;1:32.

3. Amarante RDM, Castro R, Lage AV, Cisternas JR. Diabetes Mellitus como fator de risco na aterogênese. Arq Med Hosp Fac Cienc Med Santa Casa São Paulo. 2007;52(3):87-93.

4. Bonetti PO, Lerman LO, Lerman A. Endothelial dysfunction: a marker of atherosclerotic risk. [Review] Arterioscler Thromb Vasc Biol. 2003;23(2):168-75

5. Pimenta M, Bringhenti I Souza-Mello V, Dos Santos Mendes IK, Aguila MB, Mandarin-de-Lacerda CA High-intensity interval training beneficial effects on body mass, blood pressure, and oxidative stress in diet-induced obesity in ovariectomized mice. Life Sci. 2015;139:75-82.

6. Cancello R. Clément K. Is obesity an inflammatory illness? Role of low-grade inflammation and macrophage infiltration in human white adipose tissue. BJOG. 2006;113(10): 1141-7.

7. Harman D. The Free Radical Theory of Aging. Antioxid Redox Signal. 2003;5(5):557-61

8. Sassi F. Obesity and the economics of prevention: fit not fat. OECD [Internet]. 2010. [acesso em 2017 setembro, 12]; 23-44. Disponível em: https://www.oecd.org/els/health-systems/46044572.pdf

9. Amorim PR, Faria FR. Dispêndio energético das atividades humanas e sua repercussão para a saúde. Motricidade. 2012; 8(2): 295-302.

10. Warburton DE, Nicol CW, Bredin SS. Health benefits of physical activity: the evidence. CMAJ. 2006;174(6):801-9.

11. Sijie T, Hainai Y, Fengying $Y$, Jianxiong W. High intensity interval exercise training in overweigh young womem. J Sports Med Phys Fitness. 2012;52(3):255-62.

12. Almeida PA, Pires CM. A importância do treinamento intervalado em programas de redução de peso e melhoria da composição corporal. EFDeportes. 2008:13(119).

13. Astorino TA, Schubert MM, Palumbo E, Stirling D, Mcmillan DW. Effect of two doses of interval training on maximal fat oxidation in sedentary women. Med Sci Sports Exerc. 2013; 45(10):1878-86.

14. Higa TS, Spinola AV, Fonseca-Alaniz MH, Evangelista FS. Comparison between cafeteria and high-fat diets in the induction of metabolic dysfunction in mice. Int J Physiol Pathophysiol Pharmacol. 2014; 6(1):47-54

15. Ferreira JC, Rolim NP, Bartholomeu JB, Gobatto CA, Kokubun E, Brum PC. Maximal lactate steady state in running mice: effect of exercise training. Clin Exp Pharmacol Physiol. 2007;8:760-765.

16. Haram PM, Kemi OJ, Lee SJ, Bendheim MO, Al-Share QY, Waldum HL, et al. Aerobic interval training vs. continuous moderate exercise in the metabolic syndrome of rats artificially selected for low aerobic capacity. Cardiovasc Res. 2009;81(4):723-32.

17. Evelson P, Travacio M, Repetto M, Escobar J, Llesuy S, Lissi E. Evaluation of total reactive antioxidant potential (TRAP) of tissue homogenates and their cytosols. Arch Biochem Biophys. 2001;388(2):261-6.

18. Ohkawa H, Ohishi N, Yagi K. Assay for lipid peroxides in animal tissues by thiobarbituric acid reaction. Anal Biochem. 1979:95(2):351-8.
19. Aksenov MY, Markesbery WR. Changes in thiol content and expression of glutathione redox system genes in the hippocampus and cerebellum in Alzheimer's disease. Neurosci Lett. 2001;302(2-3):141-5.

20. Reznick AZ, Packer L. Oxidative damage to proteins: spectrophotometric method for carbonyl assay. Methods Enzymol. 1994;233:57-63.

21. Aebi H. Catalase in Vitro. Methods Enzymol. 1984;105:121-26.

22. Wendel A. Glutathione Peroxidase. Methods Enzymol. 1981;77:325-33.

23. Marklund S. Pyrogallol Autooxidation. In: Greenwald RA (ed). Handbook of Methods for Oxygen Radical Research. CRC Press; Boca Raton, 1985:243-7.

24. Lowry OH, Rosebrough NJ, Farr AL, Randall RJ. Protein Measurement with the Folin phenol reagents. J Biol Chem. 1951;193(1):265-75

25. CruzatVF, Rogero MM, Borges MC, Tirapegui J. Aspectos atuais sobre estresse oxidativo, exercícios físicos e suplementação. Rev Bras Med Esporte. 2007;13(5):336-42.

26. Pinho RA, Silva LA, Pinho CA, Scheffer DL, Souza CT, Benetti M, et al. Oxidative stress and inflammatory parameters after an Ironman race. Clin J Sport Med. 2010;20(4):306-11.

27. Delwing-de Lima D, Ulbricht AS, Werlang-Coelho C, Delwing-Dal Magro D, Joaquim VH, Salamaia $\mathrm{EM}$, et al. Effects of two aerobic exercise training protocols on parameters of oxidative stress in the blood and liver of obese rats. J Physiol Sci. 2018;68(5):699-706.

28. Li G, Liu JY, Zhang HX, Li Q, Zhang SW. Exercise training attenuates sympathetic activation and oxidative stress in diet-induced obesity. Physiol Res. 2015;64(3):355-67.

29. Dannenmann B, Lehle S, Hildebrand DG, Kübler A, Grondona P, Schmid V, et al. High glutathione and glutathione peroxidase-2 levels mediate cell-type-specific DNA damage protection in human induced pluripotent stem cells. Stem Cell Reports. 2015;4(5):886-98

30. Motta VF, Aguila MB, Mandarim-De-Lacerda CA. High-intensity interval training (swimming) significantly improves the adverse metabolism and comorbidities in diet-induced obese mice. J Sports Med Phys Fitness. 2015;56:655-63.

31. Oh S, Tanaka K, Warabi E, Shoda J. Exercise reduces inflammation and oxidative stress in obesity-related liver diseases. Med Sci Sports Exerc. 2013;45(12):2214-22.

32. Aguiar Júnior AS, Pinho RA. Efeitos do exercício físico sobre o estado redox cerebral. Rev Bras Med Esporte. 2007:13:(5):355-60

33. Powers SK, Jackson MJ. Exercise-induced oxidative stress: cellular mechanisms and impact on muscle force production. Physiol Rev. 2008;88(4):1243-76.

34. Bogdanis GC, Stavrinou P, Fatouros IG, Philippou A, Chatzinikolaou A, Draganidis D, et al. Short-term high-intensity interval exercise training attenuates oxidative stress responses and improves antioxidant status in healthy humans. Food Chem Toxicol. 2013;61:171-7.

35. Fisher G, Schwartz DD, Quindry J, et al. Lymphocyte enzymatic antioxidant responses to oxidative stres following high-intensity interval exercise. J Appl Physiol (1985). 2011;110(3):730-37. 